\title{
Peertechz
}

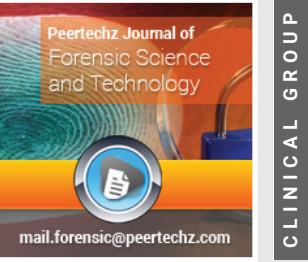

\section{The use of fungi in in the criminal investigation process}

Received: 10 October, 2020

Accepted: 26 October, 2020

Published: 27 October, 2020

*Corresponding author: Samad Jamali, Department of Plant Protection, College of agriculture, Razi University, Kermanshah, Iran, Tel: +98-917-449-8079;

E-mail: jamali454@yahoo.com

ORCID: https://orcid.org/0000-0001-9422-0618

https://www.peertechz.com

\section{Samad Jamali*}

Check for updates

Department of Plant Protection, College of agriculture, Razi University, Kermanshah, Iran

\begin{abstract}
The knowledge of forensic mycology has been formed by using the capacity of the science of fungus identification and has gradually opened its place as a tool for identifying criminals in the criminal cases of some countries. The main purpose of this study is to get acquainted with forensic mycology in the process of investigating different criminal cases and the need for the criminal system to benefit from this new method. Fungi exist in many environments, in grounds, air, air conditioners, bathrooms of houses, on wet floors, showers, dirty, and wet laundry, in dark, and humid environments as cellars, and attics and other places. Fungi can be used in criminal investigations for investigating cause of death, time of death, locating buried corpses, providing trace evidence, hallucinations, or poisonings, biological warfare and ascertaining time of deposition. In Iran, fungi have not been used in criminal investigations, although the use of fungi for these studies in the future is inevitable. During the last years many researchers have found various situations in which fungal data can provide critical evidence.
\end{abstract}

Forensic mycology is a branch of science which describes species of fungi [1]. Criminal mycologists often have not received training specific to the criminal field. Instead, their educational background is mostly a bachelor's degree in mycology or biology. Full-time jobs may be available for forensic mycologists in US federal agencies as well as private and academic institutions. Many forensic mycologists work in the field of mycology and provide consulting and contracting with forensic associations and forensic laboratories. Forensic mycology is a relatively new science. It is formed by combining the knowledge of fungi, i.e. mycology with criminology, which is the application of scientific methods in crime identification research, and includes several sub-disciplines, including morphology, molecular biology, taxonomy and systematics. Unlike criminal anthropologists, mycologists do not deal with human corpses. Their main role in research is to make the connection between evidence and crime [2]. For example, fungal spores are used to connect a suspect with a victim or crime scene. Fungal spores are produced sexually and asexually.

Because fungal spores are produced in large quantities and spread easily through the wind, spores are often found on the victim>s clothing, hair, or skin. Fungal spores are invisible to the naked eye, and different types, whether single or in combination, can be seen under a microscope and indicate the specific area in which the crime occurred. Fungal spores can act as fingerprints. If mycologists find a rare fungus near the victim, the spores of the fungus attached to the suspect>s body indicate a crime [3]. Even for common fungi, each environment has a unique set of fungi, and the uniqueness of a fungus in an area can be like a signature identifier and link a person to an object or place. The trace of spores also determines whether the body has been displaced or whether it reveals the type of area in which the original crime occurred. The first use of mycological knowledge to detect crimes in the world dates back to more than half a century [4]. The use of this knowledge in the criminal investigation process, although it seems a simple and well-known method, is limited to developed countries. In this study, while pointing to the importance of this knowledge, the need to apply it in the judicial system of the country is also investigated. Hence, two important questions in the field of forensic mycology have been answered; first, is there a need to use the knowledge of forensic mycology in Iran? Another important question is that if the judicial system in Iran is ready to accept this knowledge, what are the solutions to implement the use of this knowledge in the country? Both of these questions are discussed in detail in this study. I believe that the Iranian judicial system, along with other developed countries, has the necessary capabilities to use mycological knowledge in the process of investigating crimes, but the main component in this regard, which is the main purpose of 
this study, is to familiarize decision-making managers and employees of security, judicial and law enforcement agencies with this knowledge. With the advancement of knowledge and the passage of time, crimes also take on a new form and in accordance with them, the ways of confronting and discovering them must also be based on new knowledge. Forensic mycology actually helps the criminal investigation process as a useful and efficient tool. Areas where climate change provides more diverse vegetation have better conditions for using criminology in criminal matters, thus Iran is one of the countries where there is a better ability to use criminal mycology.

Field experiments and cases studies in mycology showed that certain chemoecologic groups of fungi can act as aboveground grave markers $[2,5-7]$. Unlike plants, fungi can also grow on, for example, stone, brick, tiles, wooden objects, paving stones, plastics, leather, textiles, and rubber $[8,9]$. Their spores may thus provide trace evidence in situations where other palynomorphs are scarce or absent. Fungal colonies on, or associated with, human cadavers can give indications of time since death as there is information on growth rates of many moulds. But the reliability of any estimates will depend on the accuracy of the identification of the fungus, the storage methods for the body, and the availability of data on the temperature and humidity at the site.

One of the first uses of fungi as a tool for the determination of time of death is demonstrated by van de Voorde and van Dijck [10]. After that, the application of mycology in forensic science have been used in criminal investigations for investigating cause of death, time of death, locating buried corpses, providing trace evidence, hallucinations, or poisonings, biological warfare and ascertaining time of deposition $[4,8,9]$.

The use of forensic mycology in solving police riddles and terrorist security crises is inevitable. The positive experience of more than half a century of using this knowledge in countries such as the United Kingdom and the United States, is one of the reasons that indicate the need for our country's judicial and security institutions to use this knowledge in solving criminal and security problems. On the other hand, terrorist threats, which have been on the rise around the world for almost a decade, require new methods of counteraction. In order for the judicial and security institutions of the country to benefit from the knowledge of forensic mycology during the handling of police cases and terrorism-related issues, which are the two main applications of forensic mycology in the world, we can use two models: Outsourcing of these services to interested institutions and organizations pointed out. Among these two models, due to the limitations of the number of specialists, the required laboratory tools and related costs, outsourcing of forensic services under the supervision of relevant institutions is proposed as a practical solution. Institutions benefiting from forensic mycology services, while equipping laboratories in universities, demand these services from them. Utilizing the services of existing laboratories and equipping them in line with the goals of forensic mycology is a successful approach that is currently being pursued in leading countries such as the United Kingdom.

\section{References}

1. Hösükler E, Erkol Z, Petekkaya S, Gündoğdu V, Samurcu H (2018) Fungal growth on a corpse: a case report Rom J Leg Med 26: 158-161. Link: https://bit.ly/2TpmE71

2. Carter DO, Tibbett $M$ (2003) Taphonomic mycota: Fungi with forensic potential. J Forensic Sci 48: 168-171. Link: https://bit.ly/31Da3Sn

3. Hawksworth DL, Wilthshire PEJ (2015) Forensic mycology: current perspectives. Research and Rep Forensic Med Sci 5: 75-83. Link: https://bit.ly/31HXqFL

4. Hawksworth DL, Wilthshire PEJ (2011) Forensic mycology: the use of fungi in criminal investigations. Forensic Sci Int 206: 1-11. Link: https://bit.ly/3jw6Gm6

5. Sagara N (1981) Occurrence of Laccaria proxima in the grave sites of cat Trans Mycol Soc Japan 22: 271-275. Link: https://bit.ly/35zfJOL

6. Fukiaru T, Osaku K, Iguchi K, Asada M (2000) Occurrence of ammonia fungi on the forest ground after decomposition of dog carcass. Nat Hist Res 6: 9-14. Link: https://bit.ly/35vKrrO

7. Cecilia TM, Noemí CM (2017) The Mycology as Forensics Tool. Adv Tech Bio Med 5: 226. Link: https://bit.ly/3mo5svm

8. Hitosugi M, Ishii K, Yaguchi T, Chigusa Y, Kurasa A, et al. (2006) Fungi can be a useful forensic tool. Leg Med 8:240- 242. Link: https://bit.ly/3oshNAo

9. Schwarz P, Dannaoui E, Gehl A, Felkse-Zech H, Birngruber CG, et al (2015) Molecular identification of fungi found on decomposed human bodies in forensic autopsy cases. Int J Legal Med 129:785-791. Link: https://bit.ly/34vIAUC

10. van de Voorde H, van Dijck PJ (1982) Determination of the time of death by fungal growth. Z Rechtsmed 89: 75-80. Link: https://bit.ly/3kvzkW3

Discover a bigger Impact and Visibility of your article publication with

Peertechz Publications

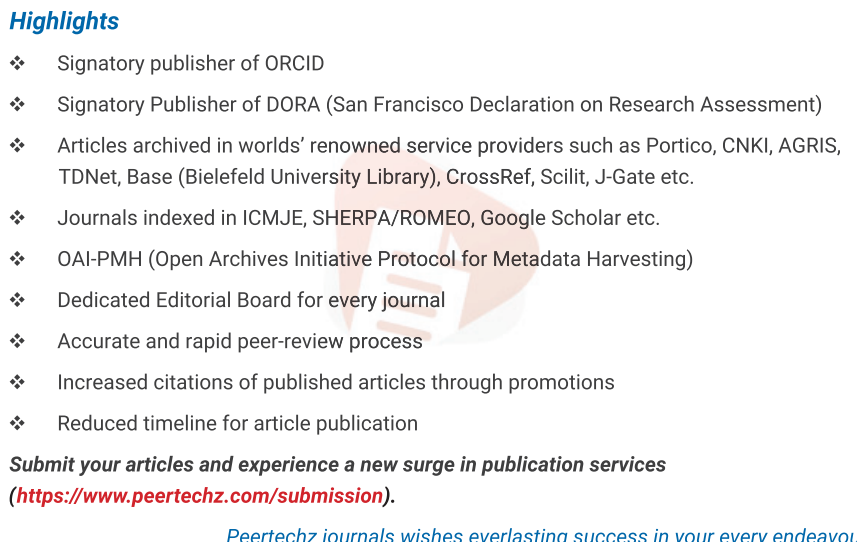

Peertechz journals wishes everlasting success in your every endeavours.

Copyright: @ 2020 Jamali S, et al. This is an open-access article distributed under the terms of the Creative Commons Attribution License, which permits unrestricted use, distribution, and reproduction in any medium, provided the original author and source are credited.

Citation: Jamali S (2020) The use of fungi in in the criminal investigation process in Iran. Forensic Sci Today 6(1): 024-025 